\title{
Electrochemical Concepts
}

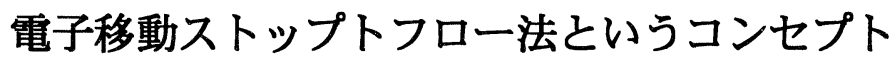

A concept of an electron transfer stopped-flow method

\author{
小山宗孝 \\ Munetaka Oyama \\ 京都大学国際融合創造センター， 干606-8501 京都市左京区吉田本町 \\ International Innovation Center, Kyoto University, Kyoto 606-8501, Japan
}

Received July 5, 2003

Abstract

In recent years, we have been engaged in the research work using an electron transfer stopped-flow method. In the present article, apart from the scientific achievements obtained with this method, I describe miscellaneous aspects of the concept of the electron transfer stopped-flow method, including the inspiration, developments, situations and applications.

Keywords: electron transfer reaction, stopped-flow method, spectroscopic detection, short-lived cation radical

はじめに

「コンセプト」というと、まずホイチョイ・ プロダクションの「気まぐれコンセプト」とい うマンガが思い浮かぶ程度で、自分としてはど ちらかというと使うのに気䎵ずかしさがある くらいの言葉なのだが、それを果敢にも論文の タイトルに使ったことがある。(“A concept of an electron transfer stopped-flow method", Electrochemistry Communications, 2, 675 (2000). [1])

今回は、このコンセプトつながりにかこつけ て、現在も研究に用いている「電子移動ストッ プトフロー法」のこれまでの進展と研究経過の、 特に周辺部を書かせていただく。

\section{コンセプトの内容}

ストップトフロー法というのは、急速に溶液 を混合したのち流通を停止した状態で反応の
進行を観測する方法である。典型的には、ピス トンドライバーを用いて 2 種類の溶液を急速 混合したのち、流通停止後に直結した光学セル 中で分光測定をおこなう（図 1）。

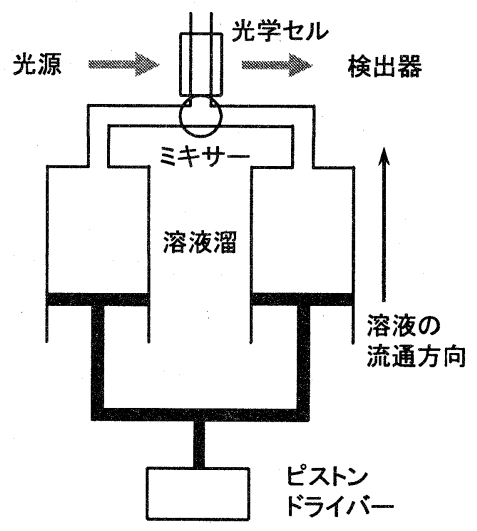

Fig. 1 Schematic diagram of a conventional stopped-flow apparatus. 
この場合の分光測定としては可視紫外吸光 測定が一般的であり、最近ではマルチチャンネ ルフォトダイオードアレー検出器の発達によ り、1ミリ秒の時間分解能で吸収スペクトル変 化が測定できる。

2 液を混合するのは、それによって反応を引 き起こすためであり、ガス圧などで急速に溶液 を混合すれば、停止した溶液中で反応開始とほ ぼ同時に反応の経時変化が観測できる。実際に は、混合開始から流通停止までのデッドタイム とよばれる時間が 1 ミリ秒以下程度あって、そ の間の反応は観測できないが、数ミリ秒の寿命 を持つ短寿命化学種に対してはこの方法で分 光検出や反応解析が可能になる。

今回の「電子移動ストップフロー法」のコン セプトというのは、「このストップトフローの 2 液混合時に電子移動反応を起こして、それに より短寿命活性種を生成したのちに分光測定 をおこなおう」という、ただそれだけの方法で ある。

実例として、不安定なカチオンラジカル $\left(\mathrm{N} \bullet^{+}\right)$を生成するもとの中性分子 $(\mathrm{N})$ の溶液と、 安定なカチオンラジカル $\left(\mathrm{M}^{\circ+}\right)$ の溶液を混合し た場合、図 2 に示すように $\mathrm{M}^{+} / \mathrm{M}$ の酸化還元 電位が $\mathrm{N}^{+} / \mathrm{N}$ の酸化還元電位よりより正であ れば、混合後の平衡は式 1 となる。

$\Delta \mathrm{E}=(\mathrm{RT} / \mathrm{nF}) \ln \left(\left[\mathrm{N}^{+}\right][\mathrm{M}]\right) /\left(\left[\mathrm{M}^{+}\right][\mathrm{N}]\right)$

その結果、 $\Delta \mathrm{E}$ が十分大きいときには、 $\mathrm{N}$ と $\mathrm{M} \bullet+$ の混合により、式 2 の反応が定量的に進行 して、混合後に光学セルにおいて N॰+の分光検 出や反応解析が可能になるはずである。

$\mathrm{N}+\mathrm{M}^{+} \rightarrow \mathrm{N}^{+}+\mathrm{M}$

(2)

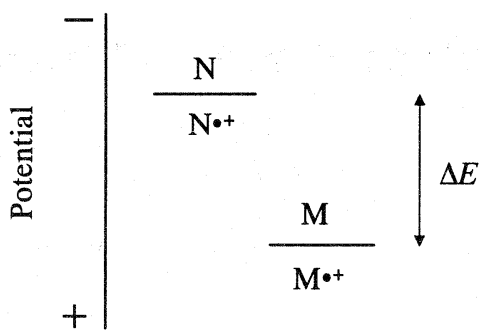

Fig. 2. Principle of the electron transfer stopped-flow method for generating $\mathrm{N}^{*}$.

\section{コンセプトまでの経緯}

この「電子移動ストップトフロー法」は原理 的に非常に簡単であり、上の例では、通常のス トップトフロー法において酸化剂として安定 な $\mathrm{M}+$ を用いるだけのことなので、新しいコン セプトとしては物足りないかもしれない。ただ、 このコンセプトに至るまでには、自分としては 紆余曲折があった。

まず、アセトニトリル中での有機カチオンラ ジカルの反応解析という目的に対しては、1985 年頃から「電解ストップトフロー法」という方 法[2]に携わってきた。この電解ストップトフ ロー法に関しては、本誌でも総説[3]として書 かせていただいたが、炭素繊維力ラム電解と同 期して溶液を光学セルに送り、流通停止後に吸 収スペクトルの時間変化を測定する方法であ る(図 3 参照)。

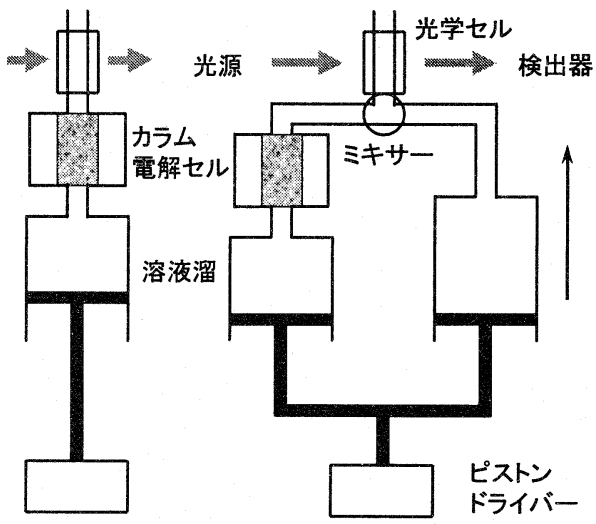

Fig.3. Schematic diagram of the electrolysis stopped-flow method. 
その研究の過程で、よく尋ねられたことのひ とつは、この解析法はどの程度短かい寿命の力 チオンラジカルまで適用できますか、という類 のことであった。

当方としては、炭素纎維電極を用いることで 定量的電解に要する時間をできるだけ短縮し ようとしたが、定電位電解では濃度に見合うだ けの時間が必要であった[4]。そのためにタイ マーと同期して最短 20 ミリ秒程度の定電流 を行ったり[4]、溶液の流通中に電解を行うよ うな方法も検討したのであるが、電極反応であ る限り電極界面での後続反応が抑え難く、電解 時間の短縮は原理的に可能であっても、実際は 困難という現状であった。

図 1 では、ミキサーから光学セルまでがデッ ドタイムであるのに対して、図3ではカラム電 解セルでの電解開始から光学セルで停止する までがデッドタイムであることの違いである。

残念ながら、 $1.8 \times 10^{3} \mathrm{M}^{-1} \mathrm{~s}^{-1}$ の二次反応速度 で二量化反応が進行するトリフェニルアミン カチオンラジカル $\left(\mathrm{TPA}^{\bullet^{+}}\right)$の可視吸収スペクト ル測定が、この方法における一応の適応限界で あった[4]。電解ストップトフロー法は、その 後も、ジフェニルアントラセンのパラ位に置換 基を導入した化合物のカチオンラジカルの反 応解析したり[5]、安定なダイカチオンやダイ アニオンの反応を解析したり[6,7]と、研究には 充分活用してきた方法ではあるが、短寿命種へ の展開という観点からは一定の限界があるこ とは否めない。<smiles>c1ccc(N(c2ccccc2)c2ccccc2)cc1</smiles>

TPA

\section{コンセプトの発案}

その後、短寿命化学種の検出や反応解析とは 別に、電解ストップトフロー法の展開として、 デュアル電解ストップトフロー発光測定法と いう方法[2,3]について検討した。

この方法は、二系列の電解セルのそれぞれで カチオンラジカルとアニオンラジカルを個別 に生成して急速混合するものであり、イオンラ ジカル間の電子移動反応に付随して起こる発 光現象を捉えようという試みである。通常の電 気化学発光測定では、電位ステップ法を用いて カチオンラジカルとアニオンラジカルを交互 に生成する方法が一般的である。そのため、図 4 における X`と $\mathrm{Y}^{\prime} \cdot$-のような電位関係にある 系での発光反応は解析可能であったが、 $\mathrm{X} ・$ と $\mathrm{Y} \cdot$-との反応解析は、電位ステップ法では電極 表面でX・が生成するために非常に困難であっ た。これに対してデュアル電解ストップトフロ 一発光測定法では、2 液を混合して発光を観測

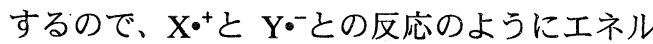
ギー差の大きいイオンラジカル間の発光観測 が可能になる[8,9]。

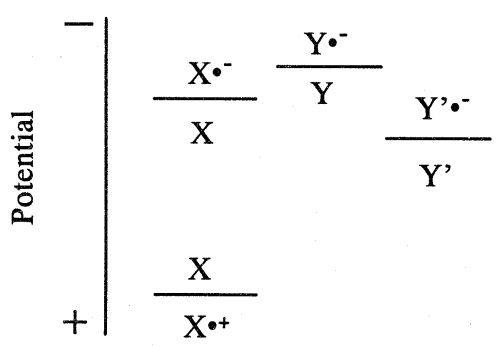

Fig. 4. Relationship of the formal potentials assumed for studying the electrogenerated chemiluminescence reactions.

本稿とは関係ないので詳細は省略するが、そ の結果を論文にまとめる段階になってはじめ て溶液内での電子移動反応について真剣に考 えるようになった（だいぶ遅いが）。つまり、 $\mathrm{X} \cdot$ • と $\mathrm{Y} ・$ ・の間の発光を考えるとき、発光反応 
（式 3 ）が進行すると、その生成物 X と残つ たY•-との間で競合する反応として式 4 の電子 移動反応が起こることも考慮しなければなら ない。

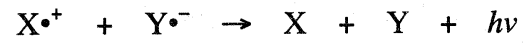

(3)

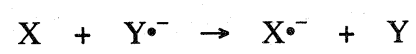

(4)

つまり、デュアル電解ストップトフロー法でも $\mathrm{X} \bullet+$ と $\mathrm{Y} \bullet$-の発光反応を高効率で捕らえるのが 難しいことを、この段階でやっと認識したわけ である。

しかし、それと同時に式 4 は式 2 と同じ道理 で進行するのであるから、「電子移動ストップ トフロー法のコンセプトを用いれば短寿命種 の反応が解析できるのではないか」ということ に、このときやっと気がついた。

このコンセプトは、セリウム(IV)イオンによ る鉄(II)イオンの酸化還元滴定のように非常に 簡単な原理だが、上記のようなことをやってみ るまで全然思いつかずに何年も過ごしてきた というのが実情である。

\section{コンセプトとしての区別化}

簡単な原理なだけに、酸化剂を用いた方法と の違いのようなものについて述べたい。

ストップトフロー法で酸化剤を用いてカチ オンラジカルを生成する試みは昔からあり、前 述した TPA・についても 1979 年に $\mathrm{Cu}(\mathrm{II})$ を用い て反応解析がおこなわれている[10]。また、そ のほかにも、 $\mathrm{Fe}(\mathrm{III}) や\left[\mathrm{Ru}(\mathrm{bpy})_{3}\right]^{3+}$ による酸化 反応でカチオンラジカルを生成して反応解析 が行われている[11,12]。さらに、カチオンラジ カルとダイカチオンの生成電位の差に応じて、 チアントレンカチオンラジカル塩と $\mathrm{NOBF}_{4}$ の 2 種類の酸化剤を使い分けて選択的に吸収ス
ペクトルを測定した結果も、これはごく最近で はあるが報告されている[13]。

しかし、酸化剂を使った場合には、酸化剤の 反応がカチオンラジカルの純粋な吸収スペク トル測定に影響を及ぼしたり、酸化剤が初段の 電子移動だけでなく後続反応にも関与してカ チオンラジカルの解析が複雑になる場合もあ る。

これに対して「電子移動ストップトフロー 法」では、式 2 のうな電位差に支配されたマ イルドな条件での電子移動によって短寿命種 を迅速かつ定量的に生成できることが特長的 である。また特に、可視部に特定の吸収を持つ 有機イオンラジカルの解析には、酸化剂である $\mathbf{M}+$ +吸収が、式 2 の電子移動反応が定量的に 進行したあとには消失してくれるのも、非常に 好都合である。実際的には、M・+の由来の吸収 が混合直後になくなることで、電子移動の進行 を確認できる利点もある。

式 2 のようなカチオンラジカルと中性分子 の電子移動反応は、ほぼ㧪散律速に近い速度で 進行することが以前に報告されている[14]。挔 散律速での反応の進行は、電子移動反応を直接 観測しようとする場合には速すぎて追跡が難 しいのでマイナスとなっても、それに後続する 化学反応解析の立場からは、カチオンラジカル 濃度などの反応初期条件を確定するのに有効 である。溶液を流通・停止して反応解析すると いうストップトフロー法の通常の操作自体も、 電子移動反応と後続化学反応のタイムラグの 点からみて、今回のコンセプトによる反応解析 に非常に適合しているように思える。

以上のような理由と、最近のマルチチャンネ ル検出器の発展によってミリ秒域で吸収スペ クトル測定が可能な現状を考えると、電子移動 反応をストップトフロー法に利用することを 区別化してひとつのコンセプトとして実現で きないかと思い、1999 年秋頃からこの研究に 着手した。 


\section{コンセプトの具体化}

コンセプトを実現するためには、まず、装置 に関しては非常に簡単である。電子移動ストッ プトフロー法の話を、電解ストップトフロー法 に絡めて少し長めにさせてもらえるときには、 装置について「電解ストップトフロー装置から 電解セルを取り除いて」などとくだらないこと を言うのだが、実際には通常のストップトフロ 一装置を使用するだけである。

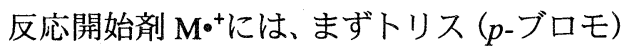
フェニルアミンカチオンラジカル $\left(\mathrm{TBPA} \bullet^{+}\right)$の 使用を考えた。TBPA・は $\mathrm{TPA} ・+に$ 比較して、パ ラ位のブロモ基のおかげで非常に安定であり、 かつその生成電位は比較的正にシフトする $\left(0.70 \mathrm{~V} \mathrm{vs} \mathrm{Fc}^{+} / \mathrm{Fc}\right)$ 。構想段階では、電解スト ップトフロー法のように電解セルを直結して、 その場で $\mathrm{TBPA}{ }^{+}$の電解生成を行うことも考え たのであるが、この頃は特に研究費がなく、ま た、バッチ電解で TBPA・のアセトニトリル溶 液をゆっくり生成しても充分安定であるため、 溶液溜に調製した TBPA•+溶液をいれる方法で 使用することにした。（その後は、さらに $\mathrm{TBPA}{ }^{+}$の $\mathrm{SbCl}_{6}$-塩(Aldrich)を使用して手を抜 くこともある。)

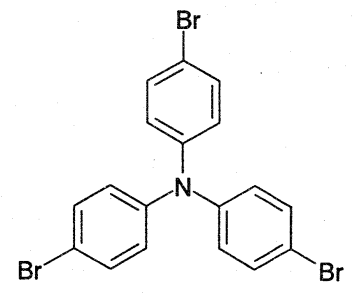

TBPA

短寿命カチオンラジカルを生成する分子 $\mathrm{N}$ としては、最初にジフェニルアミン(DPA)およ びメチルジフェニルアミン(MPA)を検討した。 これらに関しては、カラムフロー電解法では、 酸化二量化して生成したカチオンラジカルや ダイカチオンの吸収はとらえられるものの、単
量体カチオンラジカルの分光測定は困難であ つた。電気化学的にも、短寿命単量体カチオン ラジカルの検出には微小電極による高速サイ クリックボルタンメトリー法が必要だったの であるが、電子移動ストップトフロー法では、 思いのほか簡単に数十ミリ秒程度で減衰する 単量体カチオンラジカルの吸収スペクトルが 測定できた[1]。また、中性分子が速度則に関 与せず二量体の酸化平衡にのみ関与すること も明らかにできた[15]。<smiles>c1ccc(Nc2ccccc2)cc1</smiles>

DPA<smiles>CN(c1ccccc1)c1ccccc1</smiles>

MPA
電解ストップトフロー法の一応の検出限界 であった TPA•+の二次反応速度 $1.8 \times 10^{3} \mathrm{M}^{-1} \mathrm{~s}^{-1}$ に対して、 $\mathrm{DPA}^{\circ}{ }^{+}$の二量化の二次反応速度は 1.4 $\times 10^{6} \mathrm{M}^{-1} \mathrm{~s}^{-1} 、 \mathrm{MPA}{ }^{+}$の二次反応速度は $1.0 \times 10^{6}$ $\mathrm{M}^{-1} \mathrm{~s}^{-1}$ であり、この比較からも格段に短寿命種 への適用が可能になったことは明らかである。

しかし一方、この当初の一連の検討で、アセ トニトリル中でのジメチルアニリンやアニリ ンのカチオンラジカルの検出は、電子移動スト ップトフロー法でも難しいこともわかった。拡 散律側より遅いといっても、二次反応速度とし て $10^{7}$ から $10^{8} \mathrm{M}^{-1} \mathrm{~s}^{-1}$ の間に、今回の電子移動 ストップトフロー法の適用限界があるようで ある。

\section{コンセプトの展開}

\section{1. 芳香族アミンカチオンラジカル}

このように、TBPA・をを応開始剤として研 究をスタートしたのであるが、この酸化剤だけ でも、以下に示す芳香族アミン化合物のカチオ ンラジカルのアセトニトリル中での分光検出 
と反応解析が可能であった。<smiles>Nc1ccc2ccc3cccc4ccc1c2c34</smiles><smiles>CN(C)c1ccc(Br)cc1</smiles><smiles>Cc1ccc(N(C)C)cc1</smiles><smiles>COc1ccc(N(C)C)cc1</smiles><smiles>Cc1cccc(Nc2cccc(C)c2)c1</smiles>

詳細は論文[16-22]にゆずるが、実際に芳香族 アミン系のカチオンラジカルの反応を解析し てみてわかったことは、カチオンラジカルと中 性分子の反応の重要性である。これまでに二量 化反応の機構として、カチオンラジカルーカチ オンラジカルカップリングやカチオンラジカ ルー中性基質カップリングが議論されている が[23]、通常の電気化学法では、固液界面での 不均一反応であるという電極反応の本質に関 連して、明瞭には解析できない部分があって当 然だと思う。

電子移動ストップトフロー法では、 $\mathrm{N}: \mathrm{M}+{ }^{+}$ の $1: 1$ 混合で定量的に電子移動が進行する場 合には、中性分子が共存しない状態でカチオン ラジカルのみを生成できる。実際、このような 条件で実験した結果、従来の電気化学測定では 後続反応が示唆されていても、非常に安定存在 しうるカチオンラジカルもあることがわかっ た[18-20]。また、 N : M•+の混合比を変えて中 性分子 $\mathrm{N}$ が過剩の条件にすれば、電子移動反 応直後の停止した溶液中では、カチオンラジカ ルと中性分子の濃度をきちんと規定して、それ を初期条件として反応を進行させることがで きる。中性分子が反応を大きく加速し速度則に 加わるような系では、それを基に中性分子が関
与する反応機構を考察できる。

一例として、3-クロロジフェニルアミンカチ オンラジカルの減衰過程が、共存する中性分子 によってどのように変化するかを図 5 に示す。 カチオンラジカルを単独で生成したときの時 間分解吸収スペクトル（図 5A）では、各スペ クトルを 10 ミリ秒間隔で記録したのに対して、 カチオンラジカルに対して中性分子が 9 倍量 共存するときには、図 5 B に示すように 2 ミリ 秒間隔で吸収スペクトルが変化し、反応が加速 して進行する様子が顕著に見られる。この結果 からも、中性分子がカチオンラジカルの減衰反 応速度に大きく影響を及ぼすことが容易に理 解できる。

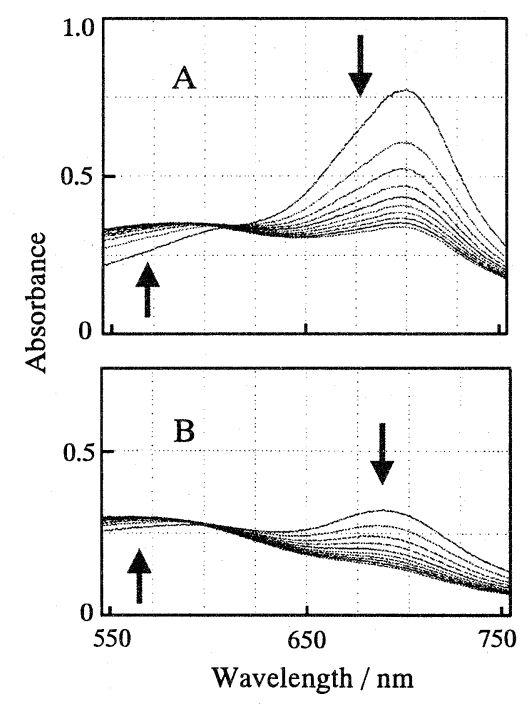

Figure 5. Time resolved absorption spectra recorded after the acetonitrile solution of 3-chloro-diphenylamine was mixed with the acetonitrile solution of $0.10 \mathrm{mM}$ TBPA ${ }^{+}$. Concentration of 3-chloro-diphenylamine: (A) 0.10 $\mathrm{mM}$, (B) $1.0 \mathrm{mM}$. Time interval of each spectrum; (A) $10 \mathrm{~ms}$, (B) $2 \mathrm{~ms}$. 
電解酸化時には電極界面でカチオンラジカ ルと中性分子の濃度勾配が生じ、かつ、中性分 子がバルクに必然的に存在する電気化学の世 界において、二量化反応や重合反応のように中 性分子が関与する可能性のある電極反応を正 しく知るためには、電子移動ストップトフロー 法のような搦め手からの情報も有用なのでは ないかと思う。

また、溶液中で中性分子がカチオンラジカル に対して大過剩に存在するような条件では、通 常の電気化学測定で観測されないような吸収 スペクトルが観測できる場合もある[24]。この ような状態の検出や明示は、活性種が関連する 溶液化学・物理化学の点からも興味深いように 思う。

\section{2. 生成可能なカチオンラジカル種の拡張}

式 1 および図 2 の原理からわかるように、電 子移動ストップトフロー法で解析可能なカチ オンラジカルの種類を増やすためには、酸化電 位がより高いカチオンラジカルを反応開始剂 $\mathrm{M}+$ •として用いるのが有効である。

この点に関しては、われわれのグループでは 合成を行う能力がないので、コンセプトがきち んと実現可能なことがわかった研究の初期段 階で、依頼合成によって展開を図った。その結 果、トリス（2,4-ジブロモ）フェニルアミン (TDBPA)を合成していただき研究を進めるこ

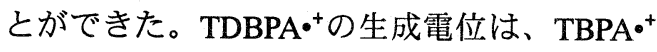
に比べて $0.44 \mathrm{~V}$ 正 (1.14 V vs Fc $\left.{ }^{+} / \mathrm{Fc}\right)$ であるた めに、TBPA・+゙電子移動生成できなかった多 環芳香族化合物のカチオンラジカルに対して も電子移動ストップトフロー法による分光検 出と反応解析が可能になった[25,26]。<smiles>Brc1ccc(N(c2ccc(Br)cc2Br)c2ccc(Br)cc2Br)c(Br)c1</smiles>

TDBPA
余談であるが、TDBPA などの種々の TPA 誘 導体の酸化電位に関しては、1980 年に詳細な 報告がある[27]。それを参考にして、依頼合成 の際の最初の目標化合物は、さらに正の酸化電 位を持つトリス（2,4,6-トリブロモ）フェニル アミンであった。この合成が非常に難しかった ようで、結局中間的に合成した TDBPA が 95\% の化合物を入手したわけである。しかし、電解 合成をおこなってみると、安定性の点からは TDBPA•+は TBPA・に比べて明らかに劣る。そ のため、実験的には TDBPA ぐらいが良かった のではないかと現在は思っている。

\section{3. 多環芳香族化合物カチオンラジカル}

TDBPA・+使用した電子移動ストップトフ ロー法の成果としては、アントラセンカチオン ラジカルの可視吸収スペクトルが検出できた 点である[25]。アセトニトリル溶媒中には微量 の水が存在するために、これまでのアントラセ ンカチオンラジカルの検出というと、微小電極 による高速サイクリックボルタンメトリーで $10,000 \mathrm{~V} / \mathrm{s}$ 程度の高速掃引速度が必要であっ た[28]。その短寿命種が分光化学的にも検出で きるわけであるから、電子移動ストップトフロ 一法がどの程度短寿命種な活性種の検出に有 効か良くわかる。

アントラセンカチオンラジカルは微量の水 との反応により 10 ミリ秒程度で完全に減衰し てしまうが、9位を置換したアントラセン誘導 体(XA)のカチオンラジカルは、置換基の反応 部位保護などの効果によりだいぶ安定化され る。そのため、アセトニトリル中でもアントラ センカチオンラジカルの 10 倍程度以上の寿 命は充分にある。よって、一定量の水やアルコ ール $(\mathrm{ROH})$ を添加して XA・減衰を観測する ことで、 $\mathrm{XA}{ }^{+}$と $\mathrm{ROH}$ との反応過程を容易に観 測できる。実際の実験操作としては、 $0.20 \mathrm{mM}$ の TDBPA•+のアセトニトリル溶液と $0.20 \mathrm{mM}$ の XA および $\mathrm{x} \mathrm{M}$ の ROH の両方を含むアセト 
ニトリル溶液を混合してやるだけでよい。混合 による電子移動反応（式５）のあとは、二倍希 釈を考慮すると、反応初期条件として $0.10 \mathrm{mM}$ $\mathrm{XA}+{ }^{+} \mathrm{x} / 2 \mathrm{M} \mathrm{ROH}$ との反応が観測できる。

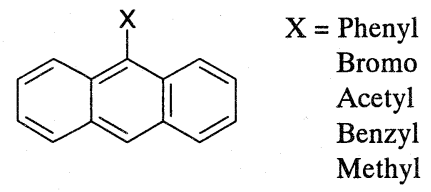

$\mathrm{XA}$

$\mathrm{XA}+\mathrm{ROH}+\mathrm{TDBPA}^{\bullet^{+}} \rightarrow \mathrm{XA}^{{ }^{+}}+$ $\mathrm{ROH}+$ TDBPA

式 5 の反応を書いたが、このとき XA が存在 しなければ TDBPA・と ROH との反応が緩やか に進行する。しかし、XAが TDBPA・と等量で 混合すれば、やはり拡散律速で電子移動反応が 進行し、結果として XA・と ROH との反応が観 測できるわけである[26]。このあたりも、後続 化学反応解析に、電子移動ストップトフローの コンセプトがうまく利用できることの一例で ある。

このような解析により、9-置換アントラセン カチオンラジカルの求核反応速度に関して反 応速度および反応機構の違いを系統的に観測 できた [26]。電解ストップトフロー法では、 電解時間中に二量化反応が進行する 9-フェニ ルアントラセンカチオンラジカルの反応さえ 解析できなかった[29]ことを考えると、電子移 動ストップトフロー法が格段に短寿命種の反 応解析に適用できることがわかる。

別の例として、ピレンと TDBPA * との等量 混合によって、アセトニトリル中でピレンカチ オンラジカルを定量的に生成した場合に観測 される時間分解吸収スペクトルを図 6 に示す。 ピレンカチオンラジカルの鋭い吸収ピークが、 30 ミリ秒程度で減衰していく様子が明瞭に 観測できた。ペリレンカチオンラジカルは非常
に安定であるが、ピレンカチオンラジカルは、 この図からもわかるように非常に反応性が高 い。ピレンの電解酸化では重合反応も報告され ているが[30,31]、アセトニトリル溶液中では中 性分子濃度を変化させても減衰速度にあまり 変化がないうえ、少量の水を添加すると減衰反 応が加速されるので、ピレンカチオンラジカル の減衰反応はアントラセンカチオンラジカル の場合と同様に、微量の水との反応によるもの と考えられる。このあたりの詳細に関しては、 置換基の影響を含めて現在検討中である。

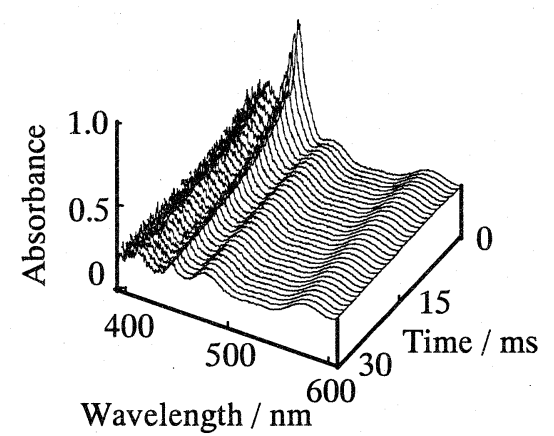

Fig. 6. Dynamic transformation of absorption spectra recorded after the acetorile solution of 0.20 $\mathrm{mM}$ pyrene was mixed with the acetonitrile solution of $0.20 \mathrm{mM}$ TDBPA ${ }^{+}$.

\section{4. クロラニルアニオンラジカル}

急にアニオンラジカルが出てくるわけだが、 かなり負の酸化電位 ( $-0.55 \mathrm{~V} \mathrm{vs.} \mathrm{Fc}^{+} / \mathrm{Fc}$ ) であ るデカメチルフェロセン(DMFc)のアセトニト リル溶液と、還元電位が比較的正 $(-0.38 \mathrm{~V}$ vs. $\left.\mathrm{Fc}^{+} / \mathrm{Fc}\right)$ であるクロラニル(ClQ)のアセトニトリ ル溶液を混合すると、電位差から予想されるよ うに、式 2 と同じ道理で式 6 のような電子移動 反応が進行する。

$\mathrm{DMFc}+\mathrm{ClQ}+\rightarrow \mathrm{DMFc}^{+}+\mathrm{ClQ}^{-}$ 
$\mathrm{w}$ この混合時に、マグネシウムイオンのよう な金属イオンを共存させておけば、均一溶液中 でのイオン対生成反応の進行を観測できる [32]。また、DMFc の代わりに Fc のような酸化 電位が正にシフトする化合物を用いてイオン 対生成条件での電子移動反応の有無を観測す れば、生成イオン対の酸化電位を見積もるよう なことも可能になる[33]。これらは、少し技巧 的ではあるが、電子移動ストップトフロー法の 応用例である。

\section{おわりに}

いままで述べていない本質的な点を最後に 書くが、このコンセプト(というか一連の研究) に対して、「電気化学ではないじゃないか」と 言われれば、全くその通りである。実際、電子 移動ストップトフロー法では、均一溶液中での 電子移動反応に伴なって進行する化学反応を 报っているだけなのだから。

しかし、「溶液内電子移動反応」や「拡散律 速」というのは電気化学にとっても重要なコン セプトであり、電極反応に興味を持っている人 間が、電極反応を考えるという立場から、今回 のような均一溶液中での詳細な反応解析をす すめてみるもの一興ではないかと思う。「チャ ージが移動すれば、それは電気化学」というの が何かのキャッチフレーズにあったように思 うので、まあ「電極のない電気化学」というこ とで、大目に見ていただきたい。

また、短寿命種の反応解析という立場からは、 光化学的手法などを用いて、もっともっと短寿 命な活性種の検出や反応解析がおこなわれて いるではないかという意見もあるかもしれな い。しかし、中性分子の影響に関連して述べた ように、反応に関与する化学種の濃度をきちん と規定することが、詳細な反応機構の解析には 必須である。電子移動ストップトフロー法では、 そのような反応解析が容易におこなえる点が 大きな特長である。また、実際の化学反応の多
くは溶液中でおこなわれ、試薬の混合で反応が 開始・進行することを考えると、拡散律速より すこし遅れたミリ秒からサブミリ秒領域の反 応に関して、解明すべき問題は、現代の化学に おいても多々あるように思う。

今回のような方法に対して、初めの報告[1] において、なぜ論文のタイトルにまでコンセプ トという語を使ったかというと、有機カチオン ラジカルの解析だけでなく、同じ原理でいろい ろなことができるのではないかと思ったから である。一番簡単に想起できることとして、還 元電位が負で安定な有機イオンラジカルによ って不安定なアニオンラジカルを電子移動生 成して、分光検出や反応解析がおこなえるはず である。

しかしそのためには、クロラニルの還元のよ うな場合を除くと嫌気性䨌囲気での実験が必 須であり、グローブボックス中に装置を設置し て実験をおこなうような必要があるだろう。こ のような研究は、経費の都合上、実現には至っ ていない。

手の内にあるような反応系を対象に、なにが しかの報告をおこなっていても、Proof of the concept にはまだ遠いのが現状である。

\section{謝辞}

本稿に関連した研究の遂行には、三菱財団平 成 12 年度自然科学研究助成、および、文部科 学省科学研究費補助金基盤研究 C (No.13640602)の助成をいただきました。記し て謝意を表します。また、TDBPA を合成して いただきました和光純薬工業株式会社に感謝 いたします。最後に、電子移動ストップトフロ 一法に関連する研究に携わった Dr. Hyun Park (現 POSCO, Pohang, Korea) および当研究グル 一プの学生諸氏に感謝申し上げます。 


\section{文献}

[1] M. Oyama, T. Higuchi and S. Okazaki,

Electrochem. Commun., 2, 675 (2000).

[2] 岡崎敏、第 5 版 電気化学便覧電気化学会

編、丸善) p. 236.

[3] 小山宗孝, Rev. Polarogr., 45, 2 (1999).

[4] M. Oyama, K. Nozaki and S. Okazaki, Anal.

Chem., 63, 1387 (1991).

[5] M. Oyama, M. Yamanuki, T. Sasaki and S. Okazaki, J. Chem. Soc., Perkin 2, 1745 (2000).

[6] M. Oyama, T. Sasaki and S. Okazaki, J. Chem. Soc., Perkin 2, 1005 (2001).

[7] M. Oyama, A. Takei, T. Hoshino and S. Okazaki, J. Chem. Soc., Perkin 2, 1631 (2000).

[8] M. Oyama and S. Okazaki, Anal. Chem., 70, 5079 (1998).

[9] M. Oyama, M. Mitani and S. Okazaki,

Electrochem. Commun., 2, 363 (2000).

[10] R. F. Nelson and R. H. Philp, Jr., J. Phys. Chem., 83, 713 (1979).

[11] C. J. Schlesener, C. Amatore and J. K. Kochi, J. Am. Chem. Soc, 106, 7472 (1984).

[12] S. Fukuzumi, I. Nakanishi and K. Tanaka, J.

Phys. Chem. A, 103, 11212 (1999).

[13] J. J. Apperloo, L. Groenendaal, H. Verheyen, M. Jayakannan, R. A. J. Janssen, A. Dkhissi, D. Beljonne,

R. Lazzaroni and J-L. Bredas, Chem. Eur. J., 8, 2384 (2002).

[14] N. Winograd and T. Kuwana, J. Am. Chem. Soc, 93, 4343 (1971).

[15] M. Oyama, T. Higuchi and S. Okazaki, J. Chem. Soc., Perkin 2, 1287 (2001).

[16] M. Oyama, T. Higuchi and S. Okazaki,

Electrochem. Commun., 3, 363 (2001).

[17] M. Oyama and T. Higuchi, J. Electrochem. Soc., 149, E12 (2002).

[18] M. Oyama, M. Goto and H. Park, Electrochem. Commun., 4, 110 (2002).

[19] M. Goto, H. Park, K. Otsuka and M. Oyama, J.
Phys. Chem. A, 106, 8103 (2002).

[20] M. Oyama and M. Goto, Indian J. Chem. A, 42, 733 (2003).

[21] H. Park and M. Oyama, J. Chem. Soc., Perkin 2, 1335 (2002).

[22] M. Oyama and M. Kambayashi, Electrochem. Commun., 4, 759 (2002).

[23] M. Schmittrl and A. Burghart, Angew. Chem. Int. Ed. Engl., 36, 2550 (1997).

[24] M. Oyama, T. Higuchi and S. Okazaki, Electrochem. Solid State Lett., 5, E1 (2002). [25] M. Oyama, J. Matsui and H. Park, Chem. Commun., 604 (2002).

[26] J. Matsui, H. Park, K. Otsuka and M. Oyama, J. Electroanal. Chem., in press (2003).

[27] W. Schmidt and E. Steckhan, Chem. Ber., 113, 577 (1980).

[28] J. O. Howell and R. M. Wightman, J. Phys .Chem., 1984, 88, 3915.

[29] M. Oyama, K. Nozaki and S. Okazaki, J.

Electroanal. Chem., 304, 61 (1991).

[30] R. J. Waltman, A. F. Diaz and J. Bargon, J.

Electrochem. Soc., 132, 631 (1985).

[31] R. J. Waltman and J. Bargon, J. Electroanal. Chem., 194, 49 (1985).

[32] M. Oyama and H. Park, J. Electroanal. Chem., 523, 79 (2002).

[33] H. Park and M. Oyama, Electroanalysis, 14, 1269 (2002).

Electrochemical Concepts 